\title{
FOREIGN DEPARTMENT
}

\author{
IN CBARGE OF \\ LAVINIA L. DOCK \\ Pro \\ TIL REGUIATIONS FOR THE SCIIOOLS FOL NURSING IN THE S'TATE
HOSPITAIS OF CUBA
}

Tine pamplilet promised us last month by Miss Hibbard has reached its, and we make the following extraets, showing how admirably Miss Hibbard and her associates lave planned the foundations of nursing in the scloools under their cliarge :

"No. 3.

\author{
" Headquarters Department of Cura, \\ "Havana, January 3, 1902.
}

"The Military Governor of Cuba, upon the recommendation of the Superin. tendent, Department of Charities, directs the publication of the following regulations for the schools for nurses of the Island of Cuba :

"I. The schools for nurses are ereated in the Island of Cuba witl power to issue diplomas to the graduates showing their fitness to practise their profession.

"II. The schools for nurses will be classified as State institutions and will be under the immediate supervision of the Department of Charities.

"III. The rules and regulations published herewith will govern the estab. lisliment and management of the schools for nurses, and all special regulations enacted by the Boards of Managers for the interior administration of hospitals to which such schools may be annexed will conform to these rules.

"H. I. ScotT,

"Adjutant Gencral."

[Notice that under this provision the musliroom schools which we have will be impossible.-Ep.]

\section{"PREA $O B L E$.}

"The object of these sehools shall bc, first, to further the best interests of the nursing profession by establishing and maintaining a universal standard for instruetion and providing students with thc proper means of cducation in the practical care of the sick; second, to secure for the students upon graduation a degree or title which will be a protection in practising their profession and be a recognized means of securing employment; third, to provide hospitals and institutions in the island with skilled service in the nursing department and proper number of graded assistants, thus conferring a benefit to the mass of suffering humanity.

"The Sehools for Nurses are State institutions, attached to lospitals for mutual benefit, but under the direct eontrol of the Department of Charities.

"General Reoulations for tile Schoods for Nurses of the Island of Cuba. “ Chapter I.

"Establishment of Schools.

"ArTICLe 1. Schools for nurses may be established in all cities of the island wherc there are public hospitals eontaining more than one lundred beds, what466 
ever their classification may be, subject to the provisions established in this general plan of regulations, after previous approval by the Department of Oharities, and inscription in the School of Medicine of. the University of Havana."

[Here the School of Medicine and the School of Nursing stand on a level.-ED.]

"ArTICLE 2. The schools will be governed by the internal regulations of the institution, excopt where said regulations are contrary to the rules established in this plan. The schools shall not comprise less than twenty students."

"ArTicle 4. A committee consisting of three members of the Central Board of Charities, appointed by the same; a professor of the School of Medicine, appointed by the dean; and a graduate nurse holding no position in any school, but laving previously flled the position of superintendent, designated by the Department of Charities, will deal with all affairs of a general character affecting the schools. All correspondence will be transmitted through the Department of Charities. This committee will meet regularly once a month, and will hold special meetings as often as necessary."

[Notice that $a$ disinterested graduate nurse holds position on this committee.-ED.]

"ARTiCLE 6. The course of instruction in each school will cover a period of three courses, of a year each, in accordance with the provisions established in the oflicial plan of the School of Medicine. Nevertheless, any student may be admitted to examination for the first year, provided she has previously completed a course of five months' study.

"ARTicle 9. At the expiration of the tbird course, the examination will take place before a board consisting of three professors of the School of Medioine and Pharmacy, appointed by the dean of the faculty. The oldest professor will preside. The degrees in this cxamination will be those established in the regulations of the School of Medicine and will be noted in the documents of the student, to be kept on file in the Department of Charities.

"ARTICLE 11. The examinations will be public and the Department of Charities will provide the building.

"Article 12. Afier the examination of the third course, the dean of the faculty will issue a diploma to each student whose exercises have been approved, which diploma shall state that said student is admitted to the practice of the profession of nursing. Said diploma will merit all authorities, as well from the courts, the respect and consideration duc all professional titles. Without this diploma, the practice of the profession of nursing is not allowed. Each school will award a silver medal to every student who obtains the diploma of nurse."

[The Cuban nurses thus begin where we have not yet arrived-at legal status.-Ev.]

\section{" CHAPTER II.}

"Admission to the School.

"ARTICLE 19. The students will receive as remuneration for their services eight dollars per month during the first year, twelve dollars during the second, and twenty-five dollars gold during the third. Each student will provide all her necessary uniforms. For the acquisition of these, the school will assign for each student of the first and second years thirty-six dollars yearly, which will remain in the cliarge of the treasurer to be spent when the superintendent may deem it 
convenient. Should a balance remain at the end of the year, it will be given over in cash to the nurse to whom the amount is credited. The nurses who abandon the school lose all right to their uniforms. They cannot be worn on the strcets, unless when rendering service. Laundry of uniforms sliall be provided for all the students at the expense of the school.

\section{" CHAPTER III.}

"Duties of the Students.

"ArTrcle 20. All students are obliged to reside in the scliools. The hours of duty for the students will be divided between day and night. They will render their services eight hours during the day, devoting the remaining four hours to meals, study, recreation, and rest, and twelve hours during the night, taking turns in such a manner that each student may be able to render her services approximately one eonsecutive month."

[Another enlightened arrangement,- the eight-hour day with time for study.-ED.]

"Article 21. During the first two years the students will not render their services out of the school. During the third year they will be able to do so during a period which will not exceed three montlis, whenever the director, in accordance with the superintendent, may deem it convenient. When the services are rendered to the sick poor, $\mathfrak{a}$ special agreement will be made with the municipal authorities. If attendance is rendered to private individuals, outside, three dollars daily and cost of transportation will be charged. This amount will be paid over to the treasurer, and after deducting a certain sum which the scloool may deem wise to give to the nurse as gratification, the balance remaining will be kept with the object of accumulating a fund destincd to be used as a prize, which in accordance with the Department of Charities will be awarded to the student who may be deemed worthy of such a distinction."

[Here, while private duty may be donc, it is at least deprived of its worst features, the commercial value and the underbidding. The Editor rcjoices.]

" ARTICLE 22. Hospitals having no school for nurses in cases of emergency can apply for nurses to the schools established in the locality, provided they pay the school annexed to the hospital in which they ronder their services the amount decided upon as gratification and the cost of transportation. The students who are employed in that capacity will figure in the pay-roll of the hospital to which the school is annexed.

"ARTICLe 25. The students will have no intercourse with the employees other than a strictly professional one. Any infraction of this order will be severely reprimanded and the director of the school shall be held responsible for such infringement."

[How will this work? Shall the leopard change his spots?-ID.]

" Chapter IV.

"Duties of the Superintendent and her Assistants.

"Article 29. The superintendent shall send to the Department of Charities every three months a written statement of the assiduity, attendance, and conduct of each student, and forward to the School of Medicine and Plarmacy a statement of the number of students inscribed in each course. Before the final examination she must send in a complete report, contrining all necessary information with regard to the documents and practical work of each student. 
" orapter v.

"Theoretical Instruction.

"ArTicle 40. The theoretical instruction will cover three terms: the school term will be from the first of October to the first of June, and the examinations will be held during the latter part of the last month.

"ARTICLE 41. The superintendent will issue to each student a tri-monthly statement of her services in accordance with the following form:

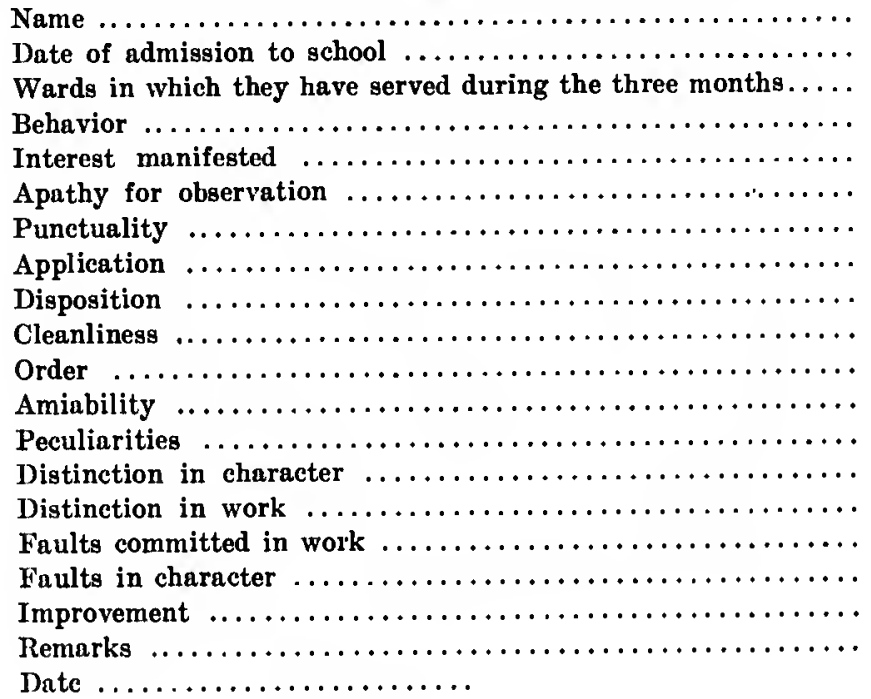

(Signature) $\ldots \ldots \ldots \ldots \ldots \ldots \ldots \ldots \ldots$

ITEMS

ONE of the most deeply interesting bits of news we have had is that a biography of Miss Florence Nightingale is in preparation with her consent and assistance. It will be written by Miss Rebecca Insley and published by Harper Brothers. All nurses will hail with delight this first adequate life of the great woman who revolutionized the care of the sick in hospital and home, and who announced in tones of unimpeachable authority all those great prineiples of sanitation and education, of ethics in discipline, management, and nursing conduct, and of the rightful province of women in the realms of sick-nursing, which no one else has been able to add to or to take from, and which form the classics of all hospital and training-sehool literature. The appearance of the book will be eagerly a waited.

Miss MoGaHey has returned to Australia, having been in England since her visit here. Shall we ever get around to see her on the other side of the world?

THRRE is a choice of books, as in friends, and the mind sinks or rises to the level of its habitual society, is subdued, as Shakespeare says of the dyer's hand, to what it works in.-Iower.L. 


\section{LETTERS}

Extracts reprinted by pcrmission from the Sixth Annual Report of the Alumna Association of the Paterson General Hospital Training-School ffor Nurses:

"Cesarea, Cappadocia, Asia Minor, May 6, 1901.

"Unlike China, Japan, and other countries more Oriental than we are, our patients do not prefer the floor to the bed, and manifest their preference by crawling under. No! our white bedsteads and 'Hartford springs' seem to suit them very well. Now and then there is one who finds them too soft, but as a rule they are easily satisfied, and pleased with what they receive. When a native gets sick in this country, his friends all gather about him and await either his recovery or death. So we could take a houseful of friends, if we would, but we admit none, and gradually, as they come to understand it, they make no objections.

"Could you look into our male ward of sixteen beds you would find fourteen of them full. Such queer fellows as our patients are! I am sure you will be intercsted to have me tell you something of them,-Turks, Greeks, Armenians, Koords, and Circassians, by the great leveller, sickness, submissive and gentle as children. Here is Osman Hama Ollah, a queer Koord, whose Turkish is so thickly sprinkled with Circassian and Russian that he is very difficult to understand. He is suffering from numerous knife-wounds in the abdomen. We do not know how he was wounded, but we suspect that it was not in a good cause. For, although he was obliged to sell his house to meet expenses, he cheerfully informs us that he will soon steal another when he gets up. Not far from him is Surlayeman, or, as we know it, Solomon. He is a tobacco-smuggler, and while making away with some tobacco he was attacked by robbers and his arm-bone shattered. Surlayeman is also a Koord, and one of our jolliest, nicest patients. Opposite him is Jelil Hadji. In this country every year many thousand pilgrims go to Mecca to worship at the shrine of Mohammed. They are tattooed and receive the name of Hadji, or pilgrims. Jelil means 'glorious,' so we have 'glorious pilgrim.' A fine-sounding name, but Jelil Hadji is anything but glorious-a dusky, swarthy gypsy or nomad from the southern countries. Hadji Byram is a gentle-voiced, refined Turk softa, or student, of the Koran. Hadji Rejib, also a.softa, is an evil-faced fellow, who, you are quite sure, hates you for an unbeliever. Mehemet Ali comes from Macedonia, a European Turk, very different from his companions, for he is a refined European gentleman.

"We have four young men nurses, all of whom speak a little English As they are ambitious to learn more, and as we find it convenient to speak another language before the patients, we do not object. Their charts are very funny, and we have many a laugh over them, as, for instance, 'Went to operating. room; came back operated.' 'He has no any special pain, but he is sorry.' 'If he turns over it is running like water from the spring.' We suppose they mean his wound. Then again, 'The puss is running down his face,' not an actual cat, just pus. Again, 'He complains of pain, but has much money yet.' Evidently someone was trying to cheat, and anything connected with money or gain is always of great interest to Oriental ininds. 
"Though their knowledge of caring for the sick is so limited, for, indeed, we could not compare it to that of the laity in European countries, - I think it true that the Oriental is most curious in his treatment of sick people,-but, as I said, with a limited knowledge and a more limited language to express it in, they soon come to understand the peculiarities of the sick. As, for instance, ' He is not so comfortable saying always bad words, but I think he is not so sick as his remarks.' Then, again, they say quite tritely, 'He was more comfortable than yesterday night. No any special reason to give, only perspired, and slept well.'

"In Turkey people rarely bathe in their own homes. In fact, they have nothing to bathe with. In every village, almost, no matter how small, there is the bath, and for flfteen paras (about two cents) they can get a very decent batl. As fond as I used to be of Turkish baths in America, I have never had the courage to try one here, though we have our own bath-room in the hospital; yet, if possiblc, before admittance every patient is sent to the bath. We find it a great convenience, and it saves us an immense amount of unpleasant work. I wish you could see some of our patients before they are 'transformed'clothes changed. I can think of nothing but animated rags, and not so very animated either, for the Oriental never hurries. Time means very little to him; he scarcely knows the day of the week or month. He doesn't know his age. When Allah calls him 'Kismet' he will go. His clock is the sun; what could time mean to him? This applies to the lower classes. I wish so many timcs for a kodak. One day not long ago I came down the stairs, and in the hall ncar the door stood an old man with flowing, white beard. He was dressed in the whitc, baggy trousers of the Orient, a fancy-colored waistcoat, over all a loose, white linen robe fancifully embroidered, a green girdle, on his head a white kefcye, or cloth, which the Arabs wear for protection from the sun. Truly, he looked as if he had just stepped out of an old Biblical picture of about the time of Abraham. I thought he was an Islam or Moslem, but as I reached him I received a profound salaam; then he pointed upward and said most dramatically, "Jesus Christ came into the world to save sinners, and whosoever believeth in Him shall not perish, but have eternal life.' I said, 'A re you an Islam ?' He replied, 'I am a prophet from the Holy City, preaching salvation.' Poor thing! he really was an Armenian from Jerusalem, and did preach, but he was insane.

"The a la Franka things in our hospital cause a great deal of wonder and surprise. For instance, our dumb-waiter. There is no name for that in Turkish. Not having any, there was no need, so they call it the cupboard that moves. While we flnd our imported things very convenient,-in fact, absolute necessities,-yet they have their disadvantages in the fact that the natives must be taught how to use them. My laundress regarded my nice American wringer as easily cooked and eaten as used for washing. Here the people wash their clothes on the rocks by a stream of water. It is very interesting to watch them. They use their feet in a kind of peculiar shuffling motion. Can you imagine how difficult it is for them to learn to wash a la Franka?

"The servant and nurse question is a difficult one to solve here, and requires almost superhuman efforts to overcome some of the problems. I have a good cook-a prompt, clean man. His cooking is, of course, a la Turka, but as that is what the patients like, it is sufficient. I do not board in the hospital. Time and effort spent in preparing delicacies for invalids would be lost here, for they will not eat them; but they are very fond of 'yoghoort,' so we 
give them that always after operalions. 'Yoghoort' is fermented milk, ruostly sheep's or goat's. It is very much like your matzoon. Matzoon was imported to Ameriea by an Armenian, and here in the Arinenian language 'yoghoort' is 'mahdzoon.' Not long ago my cook was obliged to go away for a day or so, so 1 put my washwoman in to cook during his absence. I went to the kitehen to give soue ninute directions about the meals being prompt. 1 said, 'Now, the dinner must be ready just at twelve o'clock, and as an after-thought I said, 'When is twelve o'clock?' She looked innoeently at the cloek and said, 'I don't know anything about elocks; but never mind, it does not take long to get breakfast, a little longer for supper, and still longer for dinner. Don't let your soul be squeezed; I'll work all right.' A very common and favorite expression here is ' janum sukelier'-my soul is squeezed. It is an expression I am considerably addicted to, for on oceasions, when you are so torn by conflieting emotions as to be nearly speechless, it fits perfectly.

“The people are slow to learn new things. Therc are so many custons and ways of doing things that were common to the time of Abraham. In the native louse chairs and tables are almost unknown. It is most exaspcrating to find the table which you have provided standing empty and the floor strown with things, especially if these things happen to be pus basins, etc., incident to a surgical dressing.

“I remember an experience I had nfter I had becn here about six months. In company with my native teacher and his sister, I went for a day's outing to a village. I had a few inward qualns as to how I should manage to eat it la Turka. But I knew I was in 'Rome,' and so I determined to do accordingly. When the dinner-hour arrived, a little, low stool, about a foot high, was placed in the middle of the room and covered with a fancy cloth. On this was placed a round, metal tray. Around the edge were small Turkish towels and wooden spoons. You may be sure I watched all this with considerable intercst, for I knew I had to eat. Soon a metal dish was brought in, and, with a salt-dish placed in the middle, we gathered around the table, my lost, the native Protestant preacher, my companions, and myself,-five of us,-and all to eat out of one dish, which you know is a la Oriental. Our first course was eggs, half fricd or boiled in a lot of fat, and left in. Like most nurses, I am a rapid catcr, but for once I was slow to begin, and, spoon in hand, I speculated which was my eorner of the dish. My host, seeing my hesitancy, to ise a common expression, ' licked' his spoon, stirred up my corner with his fingers, sprinkled in some salt, and again invited me to partake. For fear of further developments, I delayed no longer, and ate straight through each course. Not to have eaten wonld have been highly offensive. Yoghoort and honey mixed, black bread, flour browned in grease and sweetened with 'pikmez' (a kind of molasses made from grape-juice), meat pickled in garlic and all the strong spices for which the Orient is 'so famous, so strong and pungent that your breath retains the odor for a weck. Incongruous and queer as it all was, it was rendered still more so by secing hanging on the wall a chromo-like picture-card, and underneath in large letters 'J. \& P. Coats' thread, the best in the world.' After all, the world is not so large, is it? 


\section{MADAM TSILKA}

[Tunotin the kindness of Miss Maxwell, of the Presbyterian Hospital, New York, we have been furnislied with letters and items regarding the work of Miss Stonc, the captive missionary, and her companion, Madam Tsilka, who is a Presbyterian graduate. Her maiden nane was Katherine Demetrius Stephanova; slie was the daughter of an Eastern merchnnt of means who allowed her to attend a school, where she became a Christian. She afterwards came to America, studied at Mr. Moody's sehool in Northampton, then took a kindergarten course, and finally the course of nursing at the Presbyterian Hospital, from which she graduated in 1898. She then married the Rev. Gregory M. Tsilka, and returned with him to engage in missionary work in Albania. On September 3 last Madam Tsilka was captured, in company with Miss Stone, by brigands, as everyone knows. The news of the release of Miss Stone, with Madam Tsilka and ler child, on February 23 makes thesc letters of speeial interest at this tinic.-ED.]

Extract of letter from Madam Tsilka, written August 12, 1000, at Monastir, Macedonia:

"Do not worry about us. We are perfectly happy-both because of God's love to us and of our devotion to eacl other. We have been on a missionary tour these last two wecks. The American teachers were with us too. There were no Christians in that place, so we hired two big rooms and did our own cooking. The principal of the American sehool and Mr. Tsilka did the dish. washing. Afterwards we had a man and girl to do our work, so we devoted our time to Christian work. On the Sundays I thought Mr. Tsilka would preach himself to death. The place was so crowded that the people had to look over each others' heads. I have done a good deal of medieal and surgical work here. The people are so ignorant of the laws of health! A woman will come to me with a baby in her arms. 'Sick,' she says, 'has fcver.' A few questions, and I ask, 'Do you bathe the baby every day?' 'Oh, no! no!' she sereams, expecting my approval of her not bathing the baby. My preseription is usually castor-oil, regular feeding, and a bath every day, and in a week's time the ereature is just as bright and happy as any baby in America."

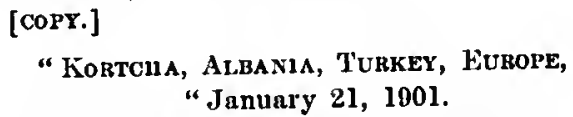

" MY deak Miss Maxwell: Since we arrived liere it scems to me as though 1 have sunk way down into the deep of tlie sea. Shut in from all communication with the civilized world, no papers, no people of enlightennent. Mail comes only twice a week, and that not to bc depended upon, for the postmaster (a Turk) distributes it whenever lie pleases. The women are ignorant as goats, for they are not allowed to go out of their houses. They think-it terrible for women to be in the presence of men. They must use neither eyes nor mouth. Obedience, and only obedienee, is their virtue. All my actions seem wonderful to thrm. The men treat we very respectfully, even the Turks. Woman is not respected because she is ignorant, and does not know how to respect herself. $I$ have more nursing and doctoring than $I$ ean possibly do. There are few doctors, whose diplonias say 'Good only for the East.' That is, they go to a 
medical sehool in Athens and study a few things, and then get a diploma with the above statement. You would have smiled if $I$ told you that I was called to a consultation by the doetors here on a ease of septiexmia. I do niss nursing nnder a eompetent doetor. They are trying to get permission from the sultan to build a hospital. I do hope that he may grant it, for it will give me a fine chance for training girls how to nurse the sick. There are very interesting cases of sickness. To-day I visited one of the Bey's (or Lord's) houses. Everything about the house was royal, but the women-ol, so blank! They showed me some of their faneywork, and their skill and taste is wonderful. There was a ehemise cmbroidered most wonderfully with gold, and its value is over eighty dollars. I do wish you eould visit here sometime. Our line of work is of every kind. My husband teaches a few hours a week in the girls' bourding-school. This sehool was daily, and this year we deeided to make it boarding, as then only we can have the giris at our cominand, and inould thcir elaraeter and training in the right direction. I plan to start a class in nursing in the school. Besides all these things, I have a house of my own to look after. My health has been perfect. Sinee I eame here I do not know that I have a stomach. The clinate is even better than that at Asheville, N. C. The only calamity is poverty, and that is because of the terrible rule of the Turks. There are rich mines, but they will not permit their opening. There is so nuch of whiclı I want to write, but, knowing how busy you are, I shall have to control mysclf. Let me say that my going to America would have becn useless had I not taken the nurse's training-it is of such a hclp to the people here.

"That I am homesick for America I cannot deny, but then I feel strongly that my duty calls me herc. I am enjoying my home life, and we arc very congenial in our work. Mr. Tsilka is so interested in my work that he pluns to take a medical course in Anerica when we come to visit. I have wished to write you long before this, but, as I said, ny timc has becn simply crowded. Please kindly remember me to Miss $I$. Welch (I do not forget her), Miss Stone, and Miss McArthur. I do not dare to expect a letter from you, but if $I$ do get one I shall be more than happy.

$$
\begin{aligned}
& \text { "Very respectfully yours, } \\
& \text { "Kathrina Stephanova Tsilka." }
\end{aligned}
$$

Extract of letter written May 16, 1901, at Kortcha, Albania:

"We have had hard work this year, and it won't be any easicr next year. No Christians at all, and training the girls is a terrible job, but, as I have cxpressed myself while yct in America, I did expect hard work. You know one wishes to accomplish so mueh in a short time. I want to have the boardingsehool well organized and then start my training of nurses, but it will take some time yet. We have no hospitals. This year I have felt so strongly the need of nurses. The world necds more the nurse than the doctor, becausc the nurse, in many eases, ean do the work of a doetor as well as of a nurse. There are a few doctors here, but they are comparatively useless. Their diplomas say 'Good only for the Orient'-that is, their work is not wanted clsewhere. I have had the whole town and surrounding villages come to me for help. Of eourse, I cannot help all, for I am not a doetor, but I ean do good in many cases. I have opened an abscess in the breast and was very suceessful, so mueh so that the doctor here reported me to the govcrnment, but the government, instead of stopping me, asked me to be a government nurse-that is, to be paid 
by the government and sent to visit any case they may ask me. But, of course, I told them that my object is not money, but to help the needy. They admired my diploma. It is a great thing to have a trained nurse in a place like this. There are some very interesting diseases here. There is one which begins with chill and fever, then eruptions at all the joints. If the patient does not eat fish and chicken he recovers, otherwise goes into consumption. This place is very healthy, but the people do not know how to guard against contagious diseases."

[COPY.]

$$
\begin{aligned}
& \text { "Salonica, TukKey, } \\
& \text { "October 7, 100l. }
\end{aligned}
$$

“Desr Miss Rroer: You will wonder why I am writing to you instead of Katharine, but what follows explains:

"On our way from Mrs. Tsilka's home to our work we were surrounded by a large group of armed men-about twenty-five in number-and carried into the forest. After that they took Miss Stone and my wife. They kept the rest of us all night, and in the morning they were gone, having carried with them Miss Stone and Katharine. It was pretty nearly one month before we got any answer from them, and now they ask one hundred thousand dollars ransom for both of them. They must be saved soon. Miss Ryder, the friend of my wife, is my friend too, so I confess that she is in the family way of six(?) months. Victor, dear little Victor, died. So please do something and col. lect as much as you can from the nurses and some of the friends, and send it by mail to Salonica, care of Dr. Houst. There is mail connection with Salonica for money-orders. Enclosed you will find a letter for Miss Belle Judd, -I have forgotten her address. Please forward it.

"Please tell the story to the following persons: Mrs. Anna Cross, 6 Washington Square, New York City; Mrs. Walton, Munn Avenue, East Orange, N. J.; Mr. Kennedy, Presbyterian Hospital, New York City; Mr. Russell Sturgis; Mrs. Kirkner, Plainfield, N. J.

"These are some of my wife's friends, whom she wants to know about it, and help if they can with something. Miss Ryder, please pray for the safety of your friend and my wife.

"Hoping this will find you well, I am

"Respectfully yours,

" Gregory M. Tsilka.

“P.S.-Letters sent to Dr. J. H. Houst, Salonica, Turkey."

\section{[COPY.]}

"Miss Lucy F. Ryder, New York.

"Vodena, Europe, Turkey.

"Drar Miss RrDer: Your letter of September 26 reached me as I was about starting for this place. I wish I could tell you of the release of our dear friend, Mrs. Tsilka, and Miss Stone. However, as to that you would have the announcement in the New York papers quite as soon as we should know it here. Perhaps I may give you some items about the capture which have not appeared in print. Mr. and Mrs. Tsilka, Miss Stone, four or five young native lady teachers, our Bible-reader,-female,- -and several boy students were captured September 3 on the road from Bansko to Djumaya. A little in advance of this party of Protestants was a man on horseback, presumably bound for 
Djumaya. This man was severely wounded, and our friends were halted by a party of brigands numbering from thirty to fifty, according to the varying estimates. One of the girls says that fiftcen rifles were pointed at them. All were obliged to dismount and go into the woods two or three miles off the road. The wounded man, who seemed to be a Iurk, walked with great difficulty, and when they came to a halt he was put out of his misery. The robbers asked for money, watches, and other valuables, but did not search pockets or use any roughness with the ladies. Mr. Tsilka, supposing that he would be taken captive, managed to pass on to his wife some money, about twenty-five dollars, which he had. First of all Miss Stone, who had been holding a summer training. school with Mrs. Tsilka's assistance, was taken off by herself. Presently Mrs. Tsilka was taken in the same direction. Tbe horse of the Turk and two muleteer horses were taken. One of the brigands came and, looking over a lot of things. scattered on the ground, picked out Miss Stone's Bible and, putting it under his arm, walked back. It is supposed that our two sisters were taken during the night to a place of safety. Mr. Tsilka and the others were kept at the halting-place, silence being enjoined. At daylight they found tbat their guards. had disappeared, and they returned in sadness to Bansko. The brigands spoke Turkish only, and were very sparing of speech. Some had their faces blackened or wore masks. Some wore Turkish uniform, others Albanian clothing, and a few were attired as shepherds. It is my opinion that they were all Bulgarians. Mr. Tsilka was at Salonica last week and wrote me that he had received three letters from his wife, written, I suppose, at the dictation of the captors to further the getting of the ransom-twenty-five thousand dollars. As to anything further, the papers have published all and more than we know. We are simply praying and waiting. It bas been a sad season for Mr. and Mrs. Tsilka. Their beautiful baby boy, Victor, whom I baptized before they started for Bansko, died of cholera infantum at the home of Mrs. Tsilka in Bansko. Then Mrs. Tsilka was dangerously ill and started to come to our annual meeting in Samskor, Bulgaria, but was stopped by quarantine until after the meeting. (In the New York Observer of September 19 I have a short quarantine experience which may interest you.) But we rejoice that our suffering friends are all persons of strong Christian character. No real evil can come to one who is in close touch with Jesus. We pity the brigands and sympathize with the captives. Mrs. Bond is here with me touring. I will pass on to Mr. Tsilka your kind word of sympathy.

"Yours most sincerely, "L. BOND." 